] O U R A L O F

French and Francophone Philosophy
RE V UE DE LA

philosophie française et de langue française

\title{
Alterity is a Negative Category of the Same
}

\section{Grant Farred}

Journal of French and Francophone Philosophy - Revue de la philosophie française et de langue française, Vol XXIV, No 1 (2016) 9-24.

\author{
Vol XXIV, No 1 (2016) \\ ISSN 1936-6280 (print) \\ ISSN 2155-1162 (online) \\ DOI $10.5195 /$ jffp. 2016.755 \\ www.jffp.org
}

\section{(c) EY-NC-ND}

This work is licensed under a Creative Commons Attribution-Noncommercial-No Derivative Works 3.0 United States License.

\section{ULIS D-Sonk}

This journal is operated by the University Library System of the University of Pittsburgh as part of its D-Scribe Digital Publishing Program, and is co-sponsored by the University of Pittsburgh Press 


\title{
Alterity is a Negative Category of the Same
}

\author{
Grant Farred
}

Cornell University

It seems impossible to make any statement about colonialism without being a dogmatist, particularly where economic organization and growth are concerned.

V.Y. Mudimbe, The Invention of Africa

Philosophical anthropology is a tradition that is as old as philosophy itself, so much so that it might be said to be indistinguishable from philosophy. Philosophical anthropology, extending as it does from Socrates to Sartre, best describes the work of V.Y. Mudimbe. ${ }^{1}$ Anthropology, broadly conceived as the science that studies human origins, the material and cultural development of humanity (philosophical anthropology concerns itself with human nature, particularly what it is that distinguishes human beings from other creatures and how philosophy allows human beings to understand themselves), is always Mudimbe's first line of philosophical inquiry. It is certainly Mudimbe's interest in anthropology that allows him to conduct his investigations into Africa, its modes of thinking, and colonialism and its continuing after-effects on the continent. Writing on the latter issue in The Invention of Africa, Mudimbe, with his customary deftness of mind, argues that colonialism and its aftermath cannot by itself account for the continent's extant condition: “The colonizing structure, even in its most extreme manifestations . . . might not be the only explanation for Africa's present-day marginality. Perhaps this marginality could, more essentially, be understood from the perspective of wider hypotheses about the classification of beings and societies." 2 Making sense of Africa, in Mudimbe's terms, must begin with a hypothesization that explicates how "beings and societies" come to be classified, the anthropological undertaking par excellence, which also requires a study of the forces that construct, implement and maintain these classifications. 
By these measures, and his own reckoning, Mudimbe stands as an "anthropological dogmatist" in his critique of the relationship between capital (capitalism) and colonialism. After all, as it pertains to colonialism's "economic reorganization" of Africa, Mudimbe is at his Foucaultian best in The Invention of Africa, delineating how Europe set about the "procedure of acquiring, distributing, and exploiting lands in colonies; the policies of domesticating the natives; and in the manner of managing ancient organizations and implementing new modes of production" (Mudimbe, 2). These "new modes of production," of course, produced not only new modes but an entirely new order of knowledge ("gnosis"), demanding a new way of thinking Africa - its cultural production as well as the violence done to its economic structures, structures either adapted to colonial capital or made obsolete (and even recidivist) by it. The effects of colonial capital, the particular modes of "growth" it brought into being (accompanied, of course, by strategic underdevelopment of the continent, as critics from Walter Rodney to Thomas Piketty, each in their own way, remind us), remain the most pronounced "organizational statement" that Europe made on, and in, Africa. In the face of such clarity about the European colonial project, how not, then, to evoke - as Mudimbe proposes, presupposes - the "dogmatist" in all the colonized?

And yet, philosophical anthropologist though he be, Mudimbe appears to expend a minimum of intellectual energy studying capital - its products, its effects, to say nothing of its central role in the colonial enterprise. What is more, Mudimbe's reflections on colonialism (in Africa) are of the sui generis variety, wending its way through ancient Greece, European philosophy and African-American thought as much as Africa itself. ${ }^{3}$ Hyperbolically phrased, here we have, then, the arch-philosophical anthropologist not doing as much as one might expect him to in the anthropologization of either of his two main fields ("objects") of inquiry. All this is enough to leave one with the sneaking suspicion that Mudimbe, who, while recognizing what is at stake in pronouncing on colonialism, might not himself be as much of a "dogmatist" as his statement would lead one to believe. (Nevertheless, the Mudimbean "statement" achieves a Deleuzean effect, at least the kind of effect that Deleuze ascribes to the project of Foucault the "archivist." Foucault's "endpoint is the statement, the simple inscription of what is said, the positivity of the dictum." 4 The statement possesses its own logic, a logic that is neither always "visible" nor as "hidden" from us as we might imagine. The statement is its own "word" - Logos, but we can never be sure what it means for the statement to be "true to its word.")

It is best then to not take Mudimbe at his colonial word, given its Foucaultian nuances and inflections. It would be better to heed Bogumil Jewsiecicki, one of Mudimbe's contemporaries and among his most insistent interlocutors, if we are to properly locate Mudimbe's thinking. Jewsiecicki places Mudimbe's work, because of its scope and intellectual ambitioin, in 
the mode of the "great philosophical thought of the nineteenth century which still dared to conceive of the world as an entity, to postulate its totality and to assign it a future. Mudimbe does not ignore the last representative of this thought, Marx" (966). There is, if we follow Jewsieciki's line of argument, no need for Mudimbe to anthropologize capital because that task has already been undertaken, undertaken with historic consequences for all kinds of thought, by Marx himself. But there remains, of course, the matter of "economic organization and growth," matters on which Marx had, as well know, a great deal to say; and, following Jewsiecicki's identification of Mudimbe's intellectual lineage (the inheritance Jewsiecicki assigns him), it now becomes imperative to identify to "look for" - the ways in which Marx is present in Mudimbe's writing.

The Marx in Mudimbe, as it were, reveals an African thinker who understands - not surprisingly - imperial capital as entirely a more transformative, or, disruptive, phenomenon. In Mudimbe's Marxist phrasing, "colonial imperialism [is the] calculated and inevitable culmination of capitalism." (In this regard Mudimbe echoes Marx in his essay, "The Future Results of British Rule in India," in which Marx writes on England's "double mission in India: one destructive, the other regenerating - the annihilation of the old Asiatic society, and the laying of the material foundations of Western society in Asia." 5 The inexorable march of colonial capitalism, the "inevitable culmination," is consonant with the creation of the "material conditions" that Marx predicts for India. ${ }^{6}$ ) The effect of this "inevitable culmination" in Africa was entirely disruptive, because the colonial experience "signified a new historical form and the possibility of radically new types of discourse on African traditions and cultures" (Mudimbe, 1). However, Mudimbe's turn to "African traditions and cultures" - longstanding interests of his - is not incidental. That is because even when Mudimbe seems most enamored of the "great philosophical thinker of the nineteenth century," when Marx is audible in his thinking, even when an analysis of uneven/unequal development is the object of his thinking (Mudimbe invoking this "new division of labor" and when his critical of the "organizational structure created under colonialism [to] bring non-Western territory into the capitalist world"), Mudimbe is unable to sustain an "economistic" - that is, the materiality, the material structure, number, figures, income disparities, and the like - thinking of capital for any considerable length of time.

In this way, Mudimbe's critique of capitalism is, at once, in its substantive turn to culture, in no way exceptional and singular. Many critics who promise a critique of imperial capital offer, in the end, many readings of cultural artifacts and pay little attention to capital. Here one need only think of Edward Said's Culture and Imperialism, where Jane Austen's Jane Eyre and Mansfield Park feature prominently, as do a host of other literary figures - T.S. Eliot, V.S. Naipual, and so on - and through the novel and 
modernist poetry and literary criticism a certain colonial mindset is discerned.

In our moment too, there are echoes of this mode of thinking the relationship between colonialism and capitalism. For all his theory of convergence and divergence, for all his graphs and the impressive accumulation of statistics, for all the data collected about early modern, modern and, of course, postmodern, economies, for all his warnings about the potential dangers posed by the resurgence of "patrimonial capital," for all the faith he puts in the hermeneutic capacity of tax data ("progressive income tax around the time of World War I (1913 in the United States, 1914 in France, 1909 in Britain, 1922 in India, 1932 in Argentina)"), 7 in his voluminous Capital in the Twenty-First Century Thomas Piketty is true to a strange dictum. It is something approximating "economic insufficiency" but more accurately, and lyrically, described as: the limits of capital, what raw numbers and economics as such cannot properly convey to us, is overcome by/in literature. In this regard, Piketty has an especial affection for Balzac and Austen. The novelists explicate, they "translate," loosely speaking, the effects of the economy into intelligible chunks; Balzac and Austen make clear, and vivid, what a David Ricardo or a Karl Marx cannot: "When Honoré de Balzac and Jane Austen wrote their novels at the beginning of the nineteenth century, the nature of wealth was clear to all readers. Wealth seemed to exist in order to procure rents, that is, dependable, regular payments to the owner of certain assets, which usually took the form of land or government bonds" (Piketty, 113). Balzac and Austen do not so much transcribe wealth as make it visible; the novelists give wealth a literary language; they define the role of wealth in the lives of nineteenth century France and England and as such they distinguish the aristocracy and the burgeoning bourgeoisie from the laboring classes. Capital in the Twenty-First Century renders realist literature as the most obvious - hiding in plain sight? - form of nineteenth century political economy. Post-World War II literature, Piketty ruefully remarks, no longer has any interest in money - in wealth, or capital accumulation, or just money for its own sake. (Here Piketty gestures toward Orhan Pamuk's novel Snow in which the protagonist explicitly wants nothing to do with money.)

The economics of politics, the project in which capital accumulation is enlisted, is most vividly illustrated through Piketty's reading of Simon Kuznets. An Russian-born (in Pinsk, in contemporary Belarus) American economist beloved by free marketers, the theorist who coined that catchy term (a great favorite of Ronald Reagan's but was first used in American politics in the early 1960s by John Kennedy), ${ }^{8}$ "a rising tide lifts all boats," Kuznets is not so much located within his moment, although that is certainly done, but identified ideologically. Kuznets' work, which influenced, among others, Milton Friedman's thinking, is held up as a champion of a free market (post-World War II) because of its propensity to reduce income 
inequality. In his study, Kuznets demonstrates a "sharp reduction in income inequality in the United States between 1913 and 1948" - attributable, as Piketty notes, to the joint effect of the two world wars and the Great Depression which shrank disparities in wealth: "Kuznets himself was well aware that the compression of high US incomes between 1913 and 1948 was largely incidental" (Piketty, 12, 14). "1913" marks that moment just before the beginning of the Great War, an event followed by the Roaring Twenties at the end of which the world was plunged into the Great Depression, another world war, followed by the Marshall Plan. After which, of course, there was the onset of decolonization in Africa, Asia, and the Caribbean.

During the Great Depression, the poor lost almost everything, and the wealthy lost a significant proportion of their assets. However, when those who own a lot whose much of it, and those who have little lose almost everything, the gap is bound to close - but there remains, nonetheless, a gap, and the difference between loss and nothing is still a yawning socioeconomic chasm. As we now know, what Kuznets named a "sharp reduction" was nothing but a historic aberration; by their very nature, aberrations are of short duration - subsequent history has since "corrected" that aberration. Income inequality today, Piketty observes, have again to resemble that of the nineteenth century, throwing the Kuznet's curve into even sharper relief. In the post-War world, as Piketty traces this new rise of capital, has again come to resemble that of the nineteenth century: "By the middle of the twentieth century, capital had largely disappeared. A little more than half a century later, it seems about to return to levels equal to those observed in the eighteenth and nineteenth centuries" (Piketty, 118). More ominously, Piketty goes on to warn, "Wealth is once again flourishing," throwing the Kuznet's curve into even sharper (but not fatal, things are never fatal for capital) relief (Piketty, 118).

In the post-War world and as a result of the "conservative revolutions" (Thatcher, Reagan) of the late-1970s, early-1980s, Kuznets' work again became the grounds for economists of his ideological persuasion ("supply siders") to read the curve as a formidable, if not unstoppable, economic trend; in Kuznetsian logic, the gap in income between rich and poor would, at worst, remain steady, at best, it would shrink ("A rising tide lifts all boats;" some more than others, of course, given the always formidable role of patrimonial capital).

Piketty, however, is quick to trace and name Kuznet's ideological project. According to Piketty, "the intent of [Kuznets'] optimistic predictions was quite simply to maintain the underdeveloped countries 'within the orbit of the free world.' In large part, then, the theory of the Kuznets curve was a product of the Cold War" (Piketty, 15). Much as Piketty is an economic historian, so Mudimbe the philosophical anthropologist is an historian of ideas - an historian of the ideas that shaped colonial, pre-colonial and postcolonial Africa, and part of Mudimbe's project is to understand what it 
meant for Africa to have been brought into the "orbit of the free world," and how that colonial freed capital (new forms of "economic organization," new modes of "growth") in Africa.

\section{Economic Insufficiency}

The history of the distribution of wealth has always been deeply political, and it cannot be reduced to purely economic mechanisms.

Thomas Piketty, Capital in the Twenty-First Century

The "distribution of wealth," according to Piketty, "is too important an issue to be left to economists, historians, and philosophers. It is of interest to everyone, and that is a good thing" (Piketty, 2). It strikes Piketty as an especially "good thing" that the "distribution of wealth" is "of interest" to "novelists." Nineteenth century novels such as "Germinal, Oliver Twist, and Les Miserables," Piketty reminds us, "did not spring from the imaginations of their authors any more than did laws limiting child labor in factories to children older than eight (in France in 1841) or ten in the mines (in Britain in 1842)" (Piketty, 7). Emile Zola, Charles Dickens and Victor Hugo were amongst the most astute historical observers of the nineteenth century; the "imagination" of all three these writers were fired by, we may even say thrived on, the political turbulence, socio-economic injustice and upheaval, and the ideological tensions of their moment. Germinal is Zola's intensely realistic depiction of the coal miners' strike in northern France in the 1860s (the thirteenth and perhaps the best novel in Zola's Les Rougon-Macquart series); Oliver Twist is Dickens' critique of child labor, child criminality and the failure of the British state to care for its most vulnerable; and Les Miserables is Hugo's anti-monarchial masterpiece that begins in 1815 and ends with nothing less than the June Rebellion of 1832.

It was during the nineteenth century, which for Mudimbe marks a crucial moment in the colonial project, that, as Piketty argues, "British subjects began to accumulate considerable assets in the rest of the world, in amounts previously unknown and never surpassed to this day . . Clearly, the structure of wealth had been utterly transformed since the time of Mansfield Park, and so one has to hope that Austen's heroes and their descendants were able to adjust in time and follow Sir Thomas's lead by investing a portion of their land rents abroad" (Piketty, 121). Today Sir Thomas's sound economic instincts, "investing abroad," would be thought of as "diversifying your portfolio" - "investments in the West Indies in 1800 may have become investments in China or South Africa in 2010," prompting Piketty to wonder, "has the deep structure of capital really changed?" (Piketty, 115, 116) However, with growing uncertainty in European (Greece, Brexit) and Asian (Chinese environmental degradation; South Korea's 
inability to deal with health crises - MERS, for example) markets, there is increasing caution if not outright concern about international diversification. Salient, however, about Piketty's analysis is not only the ways in which he elucidates the global connections that has historically linked capital, but the way in which he privileges literature to think the economy. Balzac and Austen enjoy pride of economic place with Marx, Ricardo and Kuznets, among other economic figures.

In Capital in the Twenty-First Century it is possible, it seems, to understand, classify and name the product - that is, the material object that emerges, as expected, in the form in which it is expected - of imperial capitalism through an economic analysis. Not so with its effects, the unintended, unexpected consequences of this self-same process; for that, which seems to represent some kind of "truth" about not only imperial capital but all capital, another language, one which adheres to and inheres in, a different, less calculable, logic, another language is required.

\section{Marx, Burgkmair and the "Exotic Tribe}

In order to abolish the idea of private property, the idea of communism is completely sufficient. It takes actual communist action to abolish actual private property.

Karl Marx, Economic and Philosophic Manuscripts of 1844.

As regards this other language, Mudimbe and Piketty are only in partial agreement. Mudimbe's Invention of Africa is, of course, an entirely different project to Piketty's Capital in the Twenty-First Century. Culture, however, figures prominently in both works. For Piketty's Austen and Balzac (and we can throw in Zola, Dickens and Hugo for good measure), Mudimbe presents us with Hans Burgkmair's 1508 painting the Exotic Tribe, which depicts an African figure that can only be described as, well, "exotic," in the most Orientalist sense of the term. By the time Burgkmair completed the painting he was the acknowledged master of the Augsburg (his home town) school of painting (a school he founded), and responding to the accounts of Bartolomäus Springer's travel abroad.

As part of his preparation for his series of painting on indigenous figures (from Brazil, west and southern Africa and India), Burgkmair also read Springer's diary. "Burgkmair translated Springer's written report," writes Stephanie Leitch, "into a visual account of the places and peoples encountered by the merchant, producing multiblock woodcut, which, when set together, measures approximately seven and a half feet long. The frieze follows the journey on a series of consecutive frames showing he peoples of Guinea, the region round the Cape of Good Hope, the eastern seaboard of Africa, an assembly of assorted indigenes from India, and lastly, a procession on India's Malabar Coast."9 Burgkmair's piece also invokes for 
Mudimbe "some contemporary works directly or indirectly dealing with black figures, such as Erasmus Glasser's Moor Dancers (1480), Hieronymus Bosch's Garden of Delights (1500), Katleen the Moor Woman (1521) by Albert Durer, and at the very end of the century Cornelisz van Haarlem's Batseba (1594)" (Mudimbe, 7). Mudimbe, true to his Foucaultian predilections, contrasts Burgkmair's "Exotic Tribe" to the famous Las Meninas scene - the painter, Velasquez - with which Foucault opens The Order of Things. Specializing in woodcuts (Burgkmair was also, as Leitch too reminds us, an accomplished painter), Mudimbe's critique of the "Exotic Tribe" rests upon the ways in which Burgkmair's models - white - are made to inscribe translate into - markers of racial difference. For the European artist working with the human body in contrapposto, the Italian term for the body counterposed, balancing upon one leg, is faced with the challenge - if that is the correct term - of making racial difference legible. Burgkmair has to make blackness visible so that the "Exotic Tribe," a priori charged by an incipient sixteenth century colonialism (and, of course, Springer's travel diary), has to function as an "indication of racial or cultural differences" (Mudimbe, 7).

Mudimbe thinks the "Exotic Tribe" on terms that he variously names an expression of a "discursive order" or the "sign of an epistemological order;" in so doing, Mudimbe wrests - converts - the dogma of capitalism into an anti-colonial "discursive order." It might be more accurate, however, to describe Mudimbe's "epistemological" project as emerging from the analytical limits of economics; his intervention marks the critical insufficiency of the discourse of "economic organization and growth." Or, to offer another phrasing, in order to think the "sign of this epistemological order" - racial difference - Mudimbe must acknowledge his philosophical impatience with economics. It is in this moment that Mudimbe confronts Piketty's argument, an argument that evinces a certain cultural convergence (to invoke one of Piketty's key terms). The "history of the distribution of wealth has always been deeply political," Piketty insists, and as such "it cannot be reduced to purely economic mechanisms" (Piketty, 20). If the material effects of capital "cannot be reduced to purely economic mechanisms," thereby assigning a critical role to Balzac, Austen and Burgkmair (culture is what makes visible inequalities in the "distribution of wealth"), what remains to be thought is that mode of politics able to redress the "history of the unequal distribution of wealth." Is it capital's historic capacity to alienate (labor, but by no means only labor) that displaces critique to culture, broadly conceived? Is culture that force which "exceeds" the "alimentary imperative" (the drive to address immediate physical needs; Piketty) or "labor power" (the commodity which, according to Marx, enables the worker "to live")? (Marx, 204) Is the most insidious effect of capital, Marx asks, its utilitarian imperative? "You must make everything that is yours saleable, ie., useful" (Marx, 96; original emphasis). There is no other mode of felicity to the laws of political economy than the act of infinite commodification: everything that human beings possess, beginning with 
their bodies, is either "useful" (and therefore "saleable") or, in the logic of political economy, it must be made "useful" and therefore "saleable."10

Nevertheless, what remains salient for Piketty (and Marx, but in a distinct way) is his positing of capital as a conceptual insufficiency. However, it is precisely Piketty's determination to think beyond "purely economic mechanisms" that leaves one unprepared for his definition of capital. It comes as something of a surprise to learn that, as he says,

... when I speak of capital ... I always exclude what economists often call (unfortunately, to my mind) "human capital," which consists of an individual's labor power, skills, training, and abilities. In this book, capital is defined as the sum total of nonhuman assets that can be owned and exchanged on some market. Capital includes all forms of real property (including residential real estate) as well as financial and professional capital.

(Piketty, 46)

Piketty's determination to avoid "human capital" as part of his economic calculus might be said to echo Marx's pronouncements in the Economic and Philosophic Manuscripts of 1844. Marx's 1844 argument, part of a broader discussion about capital, labor and "estrangement," is grounded in his critique, which might also be characterized as a constitutive wariness, of the "political economist," specifically, in this instance, the "political economist" and "civil society:"

Society, as it appears to the political economist, is civil society, in which every individual is a totality of needs and only exists for the other person, as the other exists for him, in so far as each becomes a means for the other. The political economist reduces everything (just as does politics in its Rights of Man) to man, i.e., to the individual whom he strips of all determinateness so as to class him as capitalist or worker. (Marx, The Marx-Engels Reader, 101).

Working in Marx's spirit, it would seem, Piketty's analysis seeks to understand how capital works without the political economist's recourse "to man;" the "individual" is laid bare so as to "locate" the individual in relation to the means of production. For his part, Marx thinks philosophically in order to understand the relation of the worker to her- or himself in communism: "Equality is nothing but a translation of the German 'Ich=Ich' into the French, i.e., political form. Equality as the groundwork of communism is its political justification, and it is the same as when the German justifies it by conceiving man as universal self-consciousness" (Marx, 99). Communism begins from the "groundwork" of "equality," a proposition that Marx derives from the "French," so that Enlightenment must be translated into a grammatical equation. Marx renders one first person pronoun equal to (an-o/Other) first person pronoun, a formulation that makes of the "=" sign an aporia, a space to think the relation of one 
pronoun to the other and therefore a space to draw the sign itself - and the equivalences/equality implied therein - into question. "Ich=Ich" must be traced to the event of 1789 before it can be properly apprehended - thought - in German. This is, we might say, Marx translating the French Revolution, an Enlightenment of which he is critical (in his terms, the "Rights of Man" does violence to politics), into his own language, complete with the recognition of the "actual communist action" - it is "communist action" that will serve as the counter, the corrective to, the evacuated, ineffectual politics of the Enlightenment - that will be required to think that all-important, alldisruptive, "=" sign. Nothing is equal in and of itself; everything, which is to say, everyone, must be made equal. It is not for nothing that Marx warns us of the "actual action" that will need to be undertaken. It will be necessary to actually do the work of making equal.

\section{Estrangement: Marx and the 1844 Manuscripts}

As much as Piketty's line of thinking more directly invokes Marx, there remains a way in which it is Mudimbe, rather than Piketty, who is closer in spirit to the philosophical difficulties Marx raises. It is not that, as Jewsiecicki argues, Mudimbe attaches himself explicitly (there is nothing obvious about the ways in which Marx leaves his imprint on Mudimbe) to the "great philosophical thought of the nineteenth century," but that both Mudimbe and Marx, even as the latter takes issue with political economists and civil society, do not uncouple their critiques of the economy from what, in Mudimbe's terms, amounts to the issue of representation and "marginality," and what Marx names "estrangement." In this way, both Mudimbe and Marx seek to effect a language "beyond natural language [which] opens to the historicity of humankind and the human condition." A language, we might say, that can account for Marx's "estrangement" and Mudimbe's "marginality," two strands of European philosophy that produced, each in their own way, the "marginality" that Mudimbe seeks to, delicately phrased, "resolve." Or, Mudimbe's determination to make out of that "intermediate space" - "marginality" - a condition for thinking colonialism as the "new division of labor which depends upon international market," a "transformation that has meant a progressive destruction of traditional realms of agriculture and crafts" (Mudimbe, 4). More importantly, however, Mudimbe makes of the "intermediate space" an interrogative occasion. Here Mudimbe proceeds with the call to understand marginality from the "perspective of wider hypotheses about the classification of beings and societies" (Mudimbe, 6). What kind of thinking takes place in and because of the intermediate space? What does this space make possible or foreclose? What pressures, political, economic, social, intellectual, does this "projected modernity" put on the "so-called African tradition?" 
In the Economic and Philosophic Manuscripts of 1844 Marx is of course delineating the different dominant modes of transcendence as they obtain in France and Germany: "the transcendence of the estrangement always proceeds from that form of estrangement which is the dominant power. In Germany, self-consciousness; in France, equality" (Marx, 99). In Marx's distinction between these two societies, between their philosophical traditions, there resides impossible equivalence that addresses itself to us as an audible equivocation, a reluctance to dismiss these differing modes of transcendence out of hand (there is also a reference that follows this on English politics); girded by a determination to recognize the effect of their combative singularity.

It is for this reason that Marx's equivocation invites a thinking together, a translation of one transcendence into the other. How do we render French equality into German self-consciousness? In rendering, however tentatively, French "equality" as the German equation, "Ich=Ich," what becomes possible is the thinking of the self-conscious " $\mathrm{I}$ " in relation to itself as a political being, as the subject of, made by, that political formation named "communism" and how that "I" is distinct, or, at the very least, conceptually discernible, from the "I" of French equality ("je"; " $\mathrm{j}$ ") ; that is, the Enlightenment of which Marx is so critical. Under these circumstances, it is possible to conjecture as to the terms under which the "Ich" communist can come into itself. The "Ich," it seems fair to say, is an "Ich" that is not yet equal to itself: "IchfIch." The "Ich" is always, in Derrida's terms, the "Ich" of the come (which is never, of course, a temporal postponement or promise, but it certainly retains a temporal dimension), the "Ich" that belongs to a politics of justice and, dare one say it?, a greater "equivalence" when each and every "Ich" will be equal to each and every other "Ich." Through the force of Marx's critique, the "Ich" might not be equal to itself, but it will be, under the possibility that is communism, less unequal. The "Ich" will, as it were, stand closer to itself.

Marx's "Ich" of the 1844 Manuscripts seems to bear this out because it recognizes that the "Ich" is that "I," to translate Marx yet one more time, that is "not yet produced by man's own labour." It is only the "political form" of communism that contains within it the possibility of allowing the "Ich" to stand in its proper historical (communist) relation to itself - in Marx's fulfilled vision, the "overcoming" of alienation and estrangement. The "Ich" can only be equal to itself when it achieves, in that memorable Marxist phrase, the "negation of the negation" (Marx, 99). That is, the "Ich" that is equal to "Ich" is the "Ich" that is achieved through the revolution that is the "negation of private property" (Marx, 99). It is only through the revolution that the "Ich" can come into, can be, itself; it is only "negation" as such that will allow human being to arrive at a very different articulation of self: the "Ich" unmediated, the "Ich" possessed of "human essence" (Marx, 99). 
By tracing "human essence" through communism itself, the "negation of the negation," Marx lends a new salience - or a renewed significance - the issue of "human capital." Specifically, the 1844 Manuscripts present us with a question for Piketty: is it possible to critique capital without attending to human capital? What would be the cost, to offer what remains a nagging discomfort - and, the point of disjuncture between Mudimbe and Piketty in the terms of Foucault's most insistent political question (What is the cost?, that is Foucault's question), of thinking capital sans "human essence?" To approach the issue in this way is also to implicitly recognize the philosophical core of Marx's thinking. Since the nineteenth century, Marx has haunted all thinking - all speculation, all theorization - on the economy. (Not only the economy, of course, but that is the focus here.) The upshot of Marx's specter is, charts or no, copious amounts of data or no (and Capital in the Twenty-First Century is remarkable in this regard), an insistence on thinking the economy philosophically. It is not simply that every subsequent economist must argue, against or with Marx, for her or his position, but that no thinking on the economy can ignore, at some point or another, its confrontation with Marx's "human essence."

\section{Marginalization}

Marginality designates this intermediate space between the so-called African tradition and the projected modernity of colonialism.

V.Y. Mudimbe, The Invention of Africa.

. . this language is a language of universal concepts which is not a natural language and which beyond natural languages opens to the historicity of humankind and the human condition.

Bogumil Jewsiecicki, "The Archeology of Invention: Mudimbe and Postcolonialism."

If German "self-consciousness" is not French "equality," if "Ich" is not " $\mathrm{je}^{\prime \prime} / \mathrm{I}^{\prime}$ '," then this is, a priori, a philosophical enterprise that echoes with Mudimbe's notion that (colonized Africa's) "alterity is a negative category of the Same." Deftly dialectical, Mudimbe elaborates, "The African has become not only the Other who is everyone else except me, but rather the key which, in its abnormal differences, specifies the identity of the Same" (Mudimbe, 12). Mudimbe offers "alterity" not as a political end in itself but as a category - pivoting on the African, the colonized - that bears the brunt of all the ideological work it takes to construct the Same (the colonizer), to "specify the identity of the Same." "Alterity/Same" is conceptually definitive because the limit of the one ("alterity") also marks the beginning of that one ("alterity"); it is only in and through the limit that "Same" and "Alterity" 
can, simultaneously, be distinguished as distinct and confront themselves as bound, that is to say, constituted, by the limit; "Alterity" is/not the "Same.".

It is for this reason that the encounter of Same-Alterity, "Ich=Ich," is the event that marks the unmistakable (haunting) resemblance of the "Same" to that which is borne within it, namely, Alterity. It is impossible, of course, to underplay the significance of Mudimbe's critique of "epistemological ethnocentricism." Mudimbe' notion arrives, full of philosophical echoes (Placide Tempels not least among them), marked by an innate difference, and yet it belongs - before itself - as Jewsiecicki intimates, to this series of distinctions. It interjects, it disrupts, in no small measure because it inserts race and colonialism itself into this discourse. However, what resonates most, other than the familiar itinerary of procedures just offered, is Jewsiecicki's insight: Mudimbe's work on "invention" is possessed of the same philosophical ambition as Marx's because it is relentless in its pursuit of the question of the "historicity of humankind and the human condition."

This shared pursuit derives from a commitment to thinking the negation - thinking is made possible because of the negation. Of course, this is a mode of apprehension that, as we will see momentarily, is far more central to Marx's work than Mudimbe's but what Mudimbe achieves through his "negative category of the Same" represents a signal accomplishment - again, Jewsiecicki's grasp of this is impressive - in the field of postcolonial theory: Mudimbe not only knows his Marx, Mudimbe thinks his problematic - the negation of the colonized black African - in terms that draw directly on Marx, terms that at once acknowledge Mudimbe's deep roots in the European philosophical tradition and indicate his ability to "translate" that tradition, to give it a philosophical language that is rooted in the nineteenth century experience of colonial Africa.

All the while, Mudimbe makes out of his philosophical "alterity" that is also, because of the violence of colonialism (the violence, the structural disruption and upheaval that he names in his economic critique), a barely tolerable Sameness that is grounded in a politics of abject resistance: "In my opinion, it is useless, in the face of this ideological violence, to put all our energies like some of our elders into an attempt to "prove" our humanity or the intelligence that were long denied to us and that clever denigrators still skillfully and regularly tear to pieces in the name of reason and a science entirely in the service of political projects."

\section{VY Mudimbe, L'odeur du père}

Instead of seeking to "prove" the humanity of the colonized African, Mudimbe turns to Marx, which in turn makes us re-turn to Marx, this time in the most untimely way, through Mudimbe. This is the force of the concept, "alterity is the negative category of the Same:" it is as much a 
"negative" philosophical provocation as it enables us to properly understand Mudimbe's critique. "Alterity is a negative category of the Same" located colonial African within the paradigm of European philosophy, it places the black African (the black African's "alterity") in the midst of key European philosophical disputes, disagreements, differences; the limit iterates itself as the first, most violent but also evocative point of engagement; it is at the limit, because of the limit, that thinking must begin. As such, Mudimbe's concept is a critique of what he names the "imperial power of the Same," but its key effect is to provide, because of his detour through Marx, to a "critical understanding of Africanism;" how "alterity" came to construct - make possible - the "Same" in Africa; that is, Mudimbe traces coloniality, through Marx, directly (back) to Hegel. In addressing the "signs of an epistemological order," Mudimbe's critique of economic insufficiency not only brings to light European thinking in art, economics, philosophy, but he effectively dis-orders that epistemological "archive," to borrow from Jewsiecicki, into an account of the black African Self in both its "alterity," always the easier of the two political possibilities, and its Sameness, a much more disruptive and philosophically violent prospect; the imbrication of the post/colonial African Self in the long lineage of Western thinking. "Alterity," as it were, altered into a disjunctive, philosophically conjunctural, entangled "Sameness." Not to put too fine a point on it, "gnosis," modernity, African modernity.

Through his philosophical intervention, Mudimbe casts - to invoke W.B. Yeats - a cold, but ultimately revealing, eye on "the name of reason and science" and all the "political projects" so deriving from and served by modernity. Alterity never - simply - mirrors the Same; it is never simply the inverse of the Same. It is, rather, the most disruptive incarnation of the Same that the Same could ever hope to encounter. Alterity bears within itself that most Marxist of threats: alterity contains within itself the possibility of "negating" both Alterity and the Same. Nothing could be more frightful, nothing is potentially more devastating to the Same or Alterity than the prospect of negation. Simultaneous, joint, negation.

\section{Marx, Not Piketty}

It is possible to argue that it is only through human beings' understanding of their "human capital," the values - material (economic rewards in the form of salary, benefits, the potential for advancement, or not) and psychic (respect, equality, dignity, and so on; or, of course, the lack thereof) assigned to it, that human beings understand their place in the world; that human beings understand the possibilities the world offers or denies them. However, in his argument against "determinateness," or, overdetermination, that makes only one of two positions available, "capitalist" or 
"worker," Marx demands yet one more accounting for class. It is through class that alterity and the same confront each other politically.

Difference, then, cannot be thought economically, only philosophically. If he is to account for the effects of difference Mudimbe must create an "epistemological order" that makes it possible to think difference on its own terms, an order, a space, where human capital is a constitutive element. What Mudimbe seeks to secure is that critical terrain where "alterity" can be apprehended as a "negative category of the Same." How does Burgkmair's "Exotic Tribe" elucidate capital in ways that neither a chart of income inequality nor a table listing taxes can?

It is into this articulation of "differences" that Foucault's resonant, persistent question, "What is the cost?," not only becomes philosophically resonant but reinstates that category, "human capital," that Piketty excludes; that Piketty excludes for strategically important reasons. One question predominates in Mudimbe: what does it mean to think the difference produced by colonialism as the overdetermining "structure of inequality?" (Piketty, 19) It is the question Mudimbe will not relinquish. That is the limit of his thinking: the place he begins from, the thinking he returns us to, again and again.

${ }_{1}^{1}$ Philosophical anthropology, which bears closely upon existentialism, came fully into its own in the twentieth century, especially in Germany (where it emerged simultaneously with Heidegger) with the work Scheler (Man's Place in Nature), Helmut Plessner (The Levels of the Organic and Man), and later Arnold Gehlen (Early Man and Late Culture), Cassirer (An Essay on Man) and then Sartre (Critique of Dialectical Reason). The main critics of philosophical anthropology, Althusser and Foucault, argue that there are either no such general features or that none are discernible (certainly none that can be relied upon) outside of the biological sciences. Mudimbe, for his part, indebted to Foucault though he be, seems to draw - easily, it seems, and certainly without apology - from anthropology to elucidate his philosophical claims.

2 VY Mudimbe, The Invention of Africa: Gnosis, Philosophy, and the Order of Knowledge (Bloomington: Indiana University Press, 1994), 6.

${ }^{3}$ It is precisely because Mudimbe thinks in this philosophically anthropological way that he was, for example, one of the key critics of Martin Bernal's Black Athena. See also The Mudimbe Reader, eds. Pierre-Philippe Fraiture and Daniel Orrells (Charlottesville: University of Virginia Press, 2016), especially "Part II: Anthropology and the Postcolonial" and "Part III: Classical Antiquity and African Modernity."

${ }^{4}$ Gilles Deleuze, Foucault, translated and edited by Seán Hand (London: The Athlone Press, 1988), 15. In the Archeology of Knowledge Foucault renders the statement in its full complexity. The statement is neither a "secret" nor fully "intelligible," which leads Foucault to declare the "statement neither visible nor hidden." Producing the statement always requires political work, sometimes, Foucault recognizes, of the performative variety. 
${ }^{5}$ Karl Marx, "The Future Results of British Rule in India," The Marx-Engels Reader, edited by Robert C. Tucker (New York: W.W. Norton \& Company, second edition, 1978), 659.

${ }^{6}$ In "British Rule in India," a letter written some 6 weeks before "The Future Results of British Rule in India," there is a wonderful moment in which Marx, after analogizing India, Italy and Ireland, dubs India the "Ireland of the East," but ultimately decides that India is, finally, a combination of Italy and Ireland.

7 Thomas Piketty, Capital in the Twenty-First Century, translated by Arthur Goldhammer (Cambridge, MA: The Belknap Press of Harvard University Press, 2014), 13.

${ }^{8}$ Kennedy was given the phrase by his speech writer, the economist Ted Sorensen. Supply-siders, largely ignore Kennedy's usage (at a September 1960 campaign speech in Ohio) and attribute, incorrectly, the phrase to Reagan.

9 Stephanie Leitch, "Burgkmair's Peoples of Africa and India (1508) and the Origins of Ethnography in Print," The Art Bulletin, Vol. 91, No. 2 (June 2009): 134.

${ }^{10}$ Later in the Manuscripts Marx extends his contemplation (making audible echoes of the Protestant ethic) on the "ethics of political economy:" "The ethics of political economy is acquisition, work, thrift, sobriety - but political economy promises to satisfy my needs. The political economy of ethics is the opulence of a good conscience, of virtue, etc.; but how can I live virtuously if I do not live? And how can I have a good conscience if I am not conscious of anything? It stems from the very nature of estrangement that each sphere applies to me a different and opposite yardstick - ethics one and political economy another; for each is a specific estrangement of man and focuses attention on a particular round of estranged essential activity, and each stands in an estranged relation to the other" (Marx, 97). 